Journal of Applied Pharmaceutical Science Vol. 6 (10), pp. 045-054, October, 2016

Available online at http://www.japsonline.com

DOI: $10.7324 / \mathrm{JAPS} .2016 .601006$

ISSN 2231-3354 (cC) BY-NC-SA

\title{
Protective and therapeutic impact of taurine on some biochemical, immunological and histological parameters in diabetic rats
}

\author{
Doaa S. Foda ${ }^{1}$, Ebtehal K. Farrag ${ }^{1}$, Nadia S. Metwally ${ }^{1 *}$, Amany S. Maghraby ${ }^{1,2}$, Abdel Razik H. Farrag ${ }^{3}$, \\ Sayed M. Rawi ${ }^{4,5}$ \\ ${ }^{1}$ Therapeutical Chemistry Department, Pharmaceutical and Drug Research Division, National Research Center, Dokki, Cairo, Egypt. ${ }^{2}$ Immune and \\ Biomarkes for Infection, National Research Center, Dokki, Cairo, Egypt. ${ }^{3}$ Pathology Department, National Research Center, Dokki ,Cairo, Egypt. \\ ${ }^{4}$ Department of Zoology, Faculty of Science, Cairo University, Egypt. ${ }^{5}$ Faculty of Sciences and Arts, King Abdulaziz University, Khulais, Kingdom of \\ Saudi Arabia.
}

\section{ARTICLE INFO}

Article history:

Received on: 05/04/2016

Revised on: 21/05/2016

Accepted on: 11/06/2016

Available online: $29 / 10 / 2016$

Key words:

Taurine, Diabetes, Insulin, Amaryl, Antioxidants Thymocytes, Splenocytes, IgG.

\begin{abstract}
Background: Taurine is a non protein amino acid found in most animal tissues. It is a powerful antioxidant which shares in combating the harmful effect of the reactive oxygen species (ROS), associated to many chronic diseases as diabetes mellitus (DM). The disease is characterized by hyperglycemia and metabolic disorders in the body that leads to the release of ROS in the cells. Methods: The present work evaluates the biochemical and immunological role of taurine $(500 \mathrm{mg} / \mathrm{kg}$ bwt) in ameliorating diabetes harm in rats when compared to the effect of the antidiabetic drug (amaryl). Six groups were established for the experiment. Group1: control rats without any supplementations. Group 2 : diabetic non treated rats. Group 3: rats received taurine for three weeks. Group 4: rats were supplemented with taurine for three weeks then injected streptozotocin (STZ) (prophylactic gp). Group 5: rats were injected with STZ then supplemented with taurine for four weeks (therapeutic gp). Group 6: rats were injected STZ then treated with amaryl drug for four weeks. Serum glucose and insulin levels in addition to liver function enzymes and lactate dehydrogenase enzyme were determined. ROS effect was monitored in liver tissue by detecting malondialdhyde resulting from lipid peroxidation and detecting glutathione reductase enzyme activity. With respect to the immunological responses, the thymocytes and splenocytes numbers were counted besides measuring serum IgG level. Histological and immunohistochemical studies were performed in pancreatic sections. Results: showed the ability of taurine in decreasing glucose level and increasing insulin with the same efficacy as amaryl drug besides affecting liver enzymes and improving the antioxidant system in cells. Taurine also restored the decrease in mean number of thymocytes and splenocytes caused by DM. Sera IgG levels from pre- and post-treatment with taurine showed non significant increase compared to the diabetic non treated group. Conclusion: post-treatment supplemention of taurine is recommended for T2DM.
\end{abstract}

\section{INTRODUCTION}

Diabetes mellitus is a major emerging clinical and public health problem in Egypt. It is defined as a metabolic disorder characterized by chronic hyperglycemia resulting from

\footnotetext{
* Corresponding Author

Nadia S. Metwally, Therapeutical Chemistry Department, Pharmaceutical and Drug Research Division. National Research Center.Cairo, Egypt.Email: nadiametwally@yahoo.com Tel: $333712111-33371499$
}

defects in insulin metabolism and impaired function in carbohydrate, lipid, and protein metabolism that leads to long term complications.

During diabetes, persistent hyperglycemia causes increased production of free radicals, especially reactive oxygen species (ROS) in all tissues as a result of glucose auto-oxidation and protein glycosylation (Robertson, 2004). The rate of diabetes risk factors is lower in rural populations in Egypt due to their traditional lifestyles. On the other side, higher rates of diabetes risk is observed in urban populations due to their higher socioeconomic status. 
It was estimated that in two different publications, the number of adults with diabetes will be more than 8 million people in the year 2030 (Herman et al., 1997; Shaw et al., 2010).

Diabetes is classified into different classes' type 1 diabetes mellitus or T1DM and type 2 diabetes mellitus or T2DM ' which are the main types. T2DM encompasses the most prevalent form of the disease. Most patients in T2DM exhibit insulin resistance and develop insulin secretary defects (Alvin et al., 2005). Interactions between adverse environmental factors and certain genetic factors are considered as a cause for T2DM (Wilson and Meigs, 2008).

Today's clinicians are presented with an extensive range of oral anti-diabetic drugs for T2DM. The most important ones are those drugs that belong to the sulphonylurea class. Sulfonylureas are rapid acting secretagogues which stimulate insulin secretion such as glimepiride (amaryl), the drug of choice in our work.

The intensive treatment of hyperglycemia with optimal drug therapy induces several side effects, as increased weight gain and hypoglycemia which can lead to higher rates of mortality (Gerstein et al,. 2008 ; Finfer et al., 2009).

As diabetes is always accompanied with an increase in free radicals and weak antioxidant defenses, so antioxidants supplementation are now suggested for antidiabetic therapy (Hisalkar et al., 2012).

Moreover the use of antioxidant therapy can regain the balance between reactive oxygen species and antioxidants which will lead to decreasing the complications induced by free radicals in diabetic patients. Consequently, the correction of oxidative stress may have important implications in preventing diabetes induced complications and reducing diabetic mortality as the intensive hypoglycemic therapies such as insulin and sulfonylureas appear to be unsuccessful in achieving this goal (Di Leo et al., 2004).

One of the most important antioxidants is the non essential amino acid "Taurine".

Taurine or 2-aminoethylsulphonic acid is a non essential, non protein amino acid. Its content in mammalian cells is altered by diet, disease and aging (Pierno et al., 1998). Taurine shares in different biological processes and plays an important role in these processes, such as insulin sensitivity and immunity (Yamori, 2006; yamori et al., 2009). According to its benefits, the researchers mentioned it as a wonder molecule (Yamori et al., 2010).

Normal taurine concentrations are essential in controlling diabetes and the impact of its consequences. Animal studies have found that having adequate taurine concentrations helps control diabetes by reducing blood glucose and restoring insulin sensitivity.

It is a known fact that taurine concentrations are lower among diabetics than they are in healthy individuals (Franconi $e t$ al., 1995).

So the present study is considered to compare between the prophylactic and therapeutic impact of tauine on diabetic rats through examining the biochemical, immunological and histological parameters.

\section{MATERIALS AND METHODS}

\section{Chemicals and Kits}

All chemicals used in the experiments were of analytical grade. Kits used for the quantitative determination of different parameters were purchased from Stanbio laboratory, Texas USA and Quinica Clinica Aplicada S.A., Spain. Taurine and Streptozotocin were purchased from Sigma Aldrich. Amaryl drug (glimepiride as active ingredient) is a product purchased by Sanofi - Aventis Egypt.

Immunological reagents were obtained from Sisco Research Lab., Mumbai, India, Biochrome KG; Berlin, Germany and KPL, Gaithersburg, MD, USA. Immunohistochemical detection kit of insulin and glucagon was purchased from FLEX Denmark.

\section{Animals}

Female albino rats of strain (Rattus rattus) weighing about $150-200 \mathrm{~g}$, obtained from the National Research Centre (Egypt) were used for the study. They were fed a standard rat pellet diet and water was provided ad libitum and maintained under standard laboratory conditions. All the studies were conducted in accordance with the Animal Ethical Committee of the National Research Center under the ethics number (09085).

\section{Experimental design}

Rats were divided into six groups (G), each group of 8 rats: G1: Normal healthy control rats. G2: Non treated diabetic control rats in which diabetes was induced by a single-dose of STZ ( $45 \mathrm{mg} / \mathrm{kg}$ bd.wt.) by i.p. injection. G3: Rats orally supplemented with taurine $(500 \mathrm{mg} / \mathrm{kg} / \mathrm{bd} . w \mathrm{t}$.) for three weeks. G4: Rats orally supplemented with taurine $(500 \mathrm{mg} / \mathrm{kg} / \mathrm{bd}$.wt.) for three weeks then injected with STZ (prophylactic group). G5: Rats injected with STZ then treated with taurine $(500 \mathrm{mg} / \mathrm{kg} / \mathrm{bd}$.wt.) for one month until normal glucose level was restored (treated group). G6: Diabetic animals treated with amaryl drug $(0.15 \mathrm{mg} / \mathrm{kg} / \mathrm{bd}$.wt) for one month until normal glucose level was restored.

\section{Streptozotocin - induced diabetes}

Rats were fasted for $16 \mathrm{hrs}$ but had free access to water, then made diabetic by a single intraperitonial dose (45 $\mathrm{mg} / \mathrm{kg} / \mathrm{bd} . w \mathrm{t}$ ) of streptozotocin (STZ) (Ramesh and Pugalendi, 2006). STZ is dissolved in 0.1M citrate buffer (pH 4.5) (Patil et al., 2006). Three days after STZ injection, rats were screened for fasted blood glucose. Blood samples were taken from lateral tail vein and glucose was determined by the blood glucose monitor Bionime GM100, produced by Taiwan. Rats had serum glucose more than $200 \mathrm{mg} / \mathrm{dl}$ were considered diabetic.

\section{Biochemical assays}

Insulin was determined in sera according to Finlay and Dillard (2007). Total cholesterol and triglycerides were estimated as a quantitative enzymatic, colorimetric method in serum according to Stein (1986) and Wahlefeld (1974) respectively. 
Serum albumin was measured quantitatively by a colorimetric method as described by Dumas and Biggs (1972).

Lactate dehydrogenase activity was kinetically measured through the oxidation of lactate to pyruvate in the presence of NAD according to Kachmar and Moss (1976).

Alkaline phosphatase (ALP) was measured colorimetricaly as described by Babson et al.( 1966). AST and ALT were measured colorimetrically according to Reitman and Frankel (1957). Total protein in liver homogenates was measured according to Beirut method according to Gornal et al. (1949). Glutathione reductase activity was measured in liver homogenates by kinetic assay as described by Erden and Bor (1984). Lipid peroxidation was determined by measuring the produced MDA by using thiobarbituric acid reactive substances (TBARS) method according to Ruiz-Larrea et al. (1994).

\section{Immunological assays}

Detection of the total number of splenocytes and thymocytes were preformed using trypan blue staining. The spleen and thymus were prepared as mentioned by Maghraby (1989). Equal volume $(0.1 \mathrm{ml})$ of whole suspension and trypan blue were mixed and examined under LEITZ microscope using Neubaur haemocytometer. Viable lymphocytes exclude the dye while dead cells appear blue. Viable lymphocytes were counted according to the equation: viable lymphocytes $=\mathrm{N} \times$ Y $2 \times 10^{4}=10^{6} / \mathrm{ml}$.

Where $\mathrm{N}$ : number of viable cells per 16 large squares. Y: the volume of cells suspension.

- Detection of IgG titers in the rat sera by enzyme linked immuno-sorbent assay (ELISA) as mentioned by Maghraby and Bahgat (2004).

\section{Histopathological examinations \\ Hematoxylin and Eosin dye technique}

Sections of $6 \mu \mathrm{m}$ thickness were prepared and stained with hematoxylin and eosin as described by Afifi (1986).

\section{Immunohistochemical assay of insulin and glucagon}

Immunohistochemical analysis of insulin and glucagon in sections of pancreas were detected by using the anti-insulin and anti-glucagon monoclonal antibodies as described by $\mathrm{Ha}$ et al. (2013).

\section{Statistical analysis}

Data were analyzed with SPSS (Statistical Package for the Social Sciences) version 9.5 software package (USA). Results were expressed as mean \pm S.E. A $p$ value of 0.05 or less was considered statistically significant.

\section{RESULTS}

\section{Biochemical results}

Changes in insulin and glucose concentrations in taurine supplemented diabetic rats

Table (1) represented the effect of taurine on glucose and insulin levels in different experimental groups. Amaryl treatment as well as taurine pre- and post-treatment decreased the elevated level of glucose in diabetic rats $(-76,64 \%-38.67 \%$ and $-70.54 \%$ respectively). However the therapeutic use exhibited better effect on insulin level than amaryl when compared to diabetic non treated animals (153.3\% and $114.7 \%$ respectively).

\section{Effect of taurine supplementation on some biochemical parameters in sera of diabetic and non diabetic groups.}

The safety of using taurine was in part considered by measuring some biochemical parameters. No significant changes was detected in total cholesterol, triglycerides, LDH, liver function enzymes and albumin level between taurine supplemented non diabetic animals and control ones. In STZ injected rats, taurine induced an improvement in all these parameters presented in table (2). With respect to the diabetic non treated group the posttreatment showed better improvements than the pre-treatment. Total cholesterol was reduced in the pre-and post-taurine treatments and amaryl by $(-13.22 \%,-28.83 \%$ and $-42.13 \%)$ respectively. The triglycerides level was also reduced in the three treatments $(-5.21 \%,-23.9 \%$ and $-26.92 \%$ respectively). LDH also expressed a reduction in its activity due to the three treatments ($24.4 \%,-37.07 \%$ and $-25.65 \%$ respectively). Total albumin showed a similar correction in the three groups where an increase in its level was observed $(18.11 \%, 57.6 \%$ and $49.8 \%$ respectively).

Table 1: Effect of taurine supplementation on glucose and insulin levels in diabetic and non diabetic rats.

\begin{tabular}{|c|c|c|c|c|c|c|}
\hline Parameters & Normal control & Diabetic & Normal taurine & $\begin{array}{c}\text { Taurine } \\
\text { pre-treated }\end{array}$ & $\begin{array}{c}\text { Taurine } \\
\text { post-treated }\end{array}$ & Amaryl drug \\
\hline Glucose (mg/dl) & $96.24 \pm 4.31$ & $495.7 \pm 13.98^{\mathrm{a}}$ & $110.0 \pm 7.90^{\mathrm{n}}$ & $304.0 \pm 19.23^{\mathrm{a},{ }^{*}}$ & $146.0 \pm 11.51^{\mathrm{a}, *}$ & $115.76 \pm 2.16^{\mathrm{n}, *}$ \\
\hline$\%$ change compared to control group & & 415.06 & 14.29 & 215.87 & 51.70 & 20.28 \\
\hline$\%$ change compared to diabetic group & & & & -38.67 & -70.54 & -76.64 \\
\hline Insulin (ng/ml) & $5.31 \pm 0.07$ & $1.69 \pm 0.07^{\mathrm{a}}$ & $5.12 \pm 0.68^{n}$ & $3.05 \pm 0.40^{\mathrm{a}, *}$ & $4.28 \pm 0.55^{\mathrm{n}, *}$ & $3.63 \pm 0.29^{\mathrm{n}, *}$ \\
\hline$\%$ change compared to control group & & -68.17 & -3.57 & -42.56 & -19.39 & -31.63 \\
\hline$\%$ change compared to diabetic group & & & & 80.47 & 153.25 & 114.7 \\
\hline
\end{tabular}

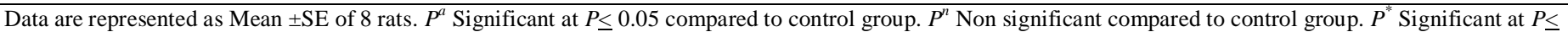
0.05 compared to diabetic group. $P^{\#}$ Non significant compared to diabetic group. 
Table 2: Effect of taurine supplementation on some biochemical parameters in diabetic and non diabetic groups.

\begin{tabular}{|c|c|c|c|c|c|c|c|}
\hline Parameters & Groups & Normal control & Diabetic & Normal taurine & $\begin{array}{c}\text { Taurine } \\
\text { pre-treated }\end{array}$ & $\begin{array}{c}\text { Taurine } \\
\text { post-treated }\end{array}$ & Amaryl drug \\
\hline Total cholesterol (mg/dl) & & $81.87 \pm 2.19$ & $214.34 \pm 37.28^{\mathrm{a}}$ & $85.67 \pm 4.29^{\mathrm{n}}$ & $186.08 \pm 10.95^{\text {a\#\# }}$ & $152.53 \pm 7.14^{\mathrm{a}^{*}}$ & $151.70 \pm 21 . .95^{\mathrm{a}^{*}}$ \\
\hline$\%$ change compared to control group & & & 161.80 & 4.64 & 127.28 & 86.30 & 85.29 \\
\hline$\%$ change compared to diabetic group & & & & & -13.18 & -28.83 & -42.13 \\
\hline Triglycerides (mg/dl) & & $80.45 \pm 1.74$ & $208.04 \pm 19.38^{\mathrm{a}}$ & $75.68 \pm 3.93^{n}$ & $197.29 \pm 13.35^{\mathrm{a}, \#}$ & $158.35 \pm 6.72^{\mathrm{a}^{*}{ }^{*}}$ & $152.21 \pm 15.20^{\mathrm{a}^{*}}$ \\
\hline$\%$ change compared to control group & & & 158.59 & -5.92 & 145.23 & 96.83 & 89.19 \\
\hline$\%$ change compared to diabetic group & & & & & -5.16 & -23.88 & -26.92 \\
\hline $\mathrm{LDH}(\mathrm{U} / \mathrm{L})$ & & $350.22 \pm 3.03$ & $749.64 \pm 11 . .24^{\mathrm{a}}$ & $357.11 \pm 19.95^{\mathrm{n}}$ & $565.92 \pm 25.86^{\mathrm{a}^{*}}$ & $471.66 \pm 23.07^{\mathrm{a}, *}$ & $557.19 \pm 26.35^{\mathrm{a}^{*}}$ \\
\hline$\%$ change compared to control group & & & 113.99 & 1.96 & 61.58 & 34.67 & 59.09 \\
\hline$\%$ change compared to diabetic group & & & & & -24.46 & -37.06 & -25.65 \\
\hline $\operatorname{Albumin}(\mathrm{g} / \mathrm{dl})$ & & $5.13 \pm 0.02$ & $2.76 \pm 0.18^{\mathrm{a}}$ & $5.07 \pm 0.38^{\mathrm{n}}$ & $3.26 \pm 0.27^{\mathrm{a}, \#}$ & $4.35 \pm 0.35^{\mathrm{a}, *}$ & $4.12 \pm 0.21^{\mathrm{a}, *}$ \\
\hline$\%$ change compared to control group & & & -46.19 & -1.16 & -36.45 & -15.20 & -19.68 \\
\hline$\%$ change compared to diabetic group & & & & & 18.11 & 57.60 & 49.27 \\
\hline
\end{tabular}

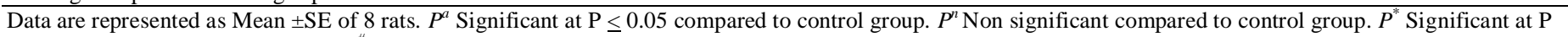
$\leq 0.05$ compared to diabetic group. $P^{\sharp}$ Non significant compared to diabetic group.

Table 3: Effect of taurine supplementation on liver function enzymes in sera of diabetic and non diabetic groups

\begin{tabular}{|c|c|c|c|c|c|c|c|}
\hline Parameters & Groups & Normal control & Diabetic & Normal taurine & $\begin{array}{c}\text { Taurine } \\
\text { pre-treated }\end{array}$ & $\begin{array}{c}\text { Taurine } \\
\text { post-treated }\end{array}$ & Amaryl drug \\
\hline$\overline{\mathrm{AST}}(\mathrm{U} / \mathrm{ml})$ & & $37.89 \pm 1.28$ & $98.8 \pm 2.12^{\mathrm{a}}$ & $40.69 \pm 1.94^{\mathrm{n}}$ & $83.09 \pm 4.25^{\mathrm{a}, *}$ & $64.99 \pm 3.27^{\mathrm{a}, \mathrm{k}}$ & $78.96 \pm 0.90^{\mathrm{a}^{*}}$ \\
\hline$\%$ change compared to control group & & & 160.75 & 7.38 & 119.29 & 71.52 & 108.39 \\
\hline$\%$ change compared to diabetic group & & & & & -15.90 & -34.22 & -20.08 \\
\hline $\operatorname{ALT}(\mathrm{U} / \mathrm{ml})$ & & $38 . .93 \pm 0.42$ & $97.4 \pm 1.29^{\mathrm{a}}$ & $40.74 \pm 2.30^{\mathrm{n}}$ & $78.55 \pm 4.62^{\mathrm{a}, *}$ & $55.53 \pm 3.89^{\mathrm{a}, *}$ & $77.26 \pm 3.43^{\mathrm{a}^{*}}$ \\
\hline$\%$ change compared to control group & & & 150.19 & 4.64 & 101.77 & 42.64 & 98.45 \\
\hline$\%$ change compared to diabetic group & & & & & -19.3 & -42.98 & -20.67 \\
\hline $\mathrm{ALP}(\mathrm{U} / \mathrm{L})$ & & $36.49 \pm 0.62$ & $98.07 \pm 2.50^{\mathrm{a}}$ & $35.11 \pm 1.97^{\mathrm{n}}$ & $76.63 \pm 4.56^{\mathrm{a}, *}$ & $54.13 \pm 3.06^{\mathrm{a}, *}$ & $80.56 \pm 2.3^{\mathrm{a},{ }^{*}}$ \\
\hline$\%$ change compared to control group & & & 168.75 & -3.78 & 110.00 & 48.34 & 120.77 \\
\hline$\%$ change compared to diabetic group & & & & & -21.86 & -44.80 & -17.85 \\
\hline
\end{tabular}

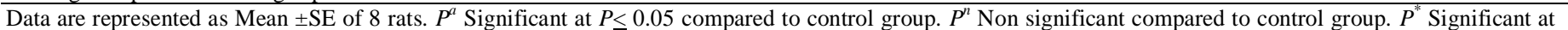
$P \leq 0.05$ compared to diabetic group. $P^{\#}$ Non significant compared to diabetic group.

\section{The impact of taurine supplementation on liver function enzymes in sera of diabetic and non diabetic groups}

Another measurement for the safety of taurine was the liver enzymes AST, ALT and ALP activities as shown in table (3). The levels of the three enzymes did not show a significant difference in taurine supplemented non diabetic rats. The pre-and post-taurine treatments and amaryl treatment exhibited positive effects on the serum liver enzymes in diabetic animals. Posttreatment with taurine exceeded this effect than the pre-treatment and amaryl. AST was reduced in the three groups (-15.9\%, $34.22 \%$ and $-20.08 \%$ respectively). A similar effect was recorded for ALT activities (-19.35\%, $-42.98 \%$ and $-20.67 \%$ respectively). All these changes were compared to diabetic non treated group.

ALP activity in taurine post-treated group showed a higher reduction $(-44.8 \%)$ than did taurine pre-treatment and amaryl treatment $(-21.86 \%$ and $-17.85 \%$ respectively).

\section{Glutathione reductase and lipid peroxidation level in liver tissue of diabetic and non diabetic groups supplemented with taurine}

For measuring the antioxidant effect of taurine on diabetes GR activity and MDA level were studied as shown in table (4). Post-treatment with taurine showed the best recovery in GR activity (102.17\%) versus diabetic non treated group. Also the pre-treatment and amaryl induced an elevation in GR activity (72.82\% and $79.07 \%$ respectively) when compared to diabetic non treated group. No great changes were found between the three treatments in the reduction of MDA level. MDA was reduced in pre-, post- taurine and amaryl treatments by $(-9.22 \%,-18.5 \%$ and $-23.39 \%$ respectively) when compared to diabetic non treated group.

\section{Immunological results \\ Total mean number of thymocytes}

Taurine supplemented normal group showed nearly similar total mean thymocyte number $(-0.11 \%)$ as the control group as shown in table (5). Taurine was able to restore the thymocyte number in the pre-treated group (24.20\%) followed by the taurine post-treated diabetic group (17.11\%), which may reflect its safe effect. The amaryl post-treated showed an increase by $(101.04 \%)$ compared to the diabetic non treated group.

\section{Total mean number of Splenocytes}

Taurine has no influence on the splenocytes number in the normal supplemented group $(-0.26 \%)$ compared to control group. No significant change was detected in the mean number of splenocytes between taurine pre-treated diabetic group $(-2.40 \%)$ and non treated group, as shown in table (5). However an elevation was observed in the post-treated $(36.59 \%)$. Amaryl exhibited the most potent effect with a percentage difference $(185.37 \%$ ) compared to diabetic non treated group. 
Table 4: Effect of taurine supplementation on glutathione reductase enzyme and lipid peroxidation in liver tissue of diabetic and non diabetic groups.

\begin{tabular}{|c|c|c|c|c|c|c|c|}
\hline Parameters & Groups & Normal control & Diabetic & Normal taurine & $\begin{array}{c}\text { Taurine } \\
\text { pre-treated }\end{array}$ & Post-treated & Amaryl drug \\
\hline$\overline{\mathrm{GR}}(\mathrm{nmol} / \mathrm{min} . / \mathrm{mg}$ protein) & & $10.94 \pm 0.24$ & $3.68 \pm 0.25^{\mathrm{a}}$ & $9.73 \pm 2.09^{n}$ & $6.36 \pm 0.82^{\mathrm{a}^{*}}$ & $7.44 \pm 0.94^{\mathrm{a},{ }^{*}}$ & $6.59 \pm 0.60^{\mathrm{a},{ }^{*}}$ \\
\hline$\%$ change compared to control group & & & -66.36 & -11.06 & -41.86 & -31.99 & -39.76 \\
\hline$\%$ change compared to diabetic group & & & & & 72.82 & 102.17 & 79.07 \\
\hline MDA (ng/gmtissue) & & $10.41 \pm 0.58$ & $21.24 \pm 0.68^{\mathrm{a}}$ & $12.11 \pm 1.27^{\mathrm{n}}$ & $19.28 \pm 1.96^{\text {a\# }}$ & $17.31 \pm 1.57^{\mathrm{a}^{, *}}$ & $16.27 \pm 1.37^{\mathrm{a}^{\mathrm{a}}}$ \\
\hline$\%$ change compared to control group & & & 104.03 & 16.33 & 85.20 & 66.28 & 56.29 \\
\hline$\%$ change compared to diabetic group & & & & & -9.22 & -18.50 & -23.39 \\
\hline
\end{tabular}

Data are represented as Mean \pm SE of 8 rats. $P^{a}$ Significant at $P \leq 0.05$ compared to control group. $P^{n}$ Non significant compared to control group. $P^{*}$ Significant at $P \leq$ 0.05 compared to diabetic group. $P^{\#}$ Non significant compared to diabetic group.

Table 5: Effect of taurine supplementation on thymocytes and splenocytes and $\operatorname{IgG}$ level in diabetic and nondiabetic groups.

\begin{tabular}{|c|c|c|c|c|c|c|c|}
\hline Parameters & Groups & Control & Diabetic & Normal taurine & $\begin{array}{c}\text { Taurine } \\
\text { pre-treated }\end{array}$ & $\begin{array}{c}\text { Taurine } \\
\text { post-treated }\end{array}$ & $\begin{array}{c}\text { Amaryl } \\
\text { drug }\end{array}$ \\
\hline Thymocytes number & & $111.43 \pm 11.23$ & $87.33 \pm 8.3^{\mathrm{n}}$ & $111.30 \pm 1.75^{\mathrm{n}}$ & $108.47 \pm 9.61^{\text {n\# }}$ & $102.28 \pm 3.86^{\mathrm{n} \#}$ & $175.57 \pm 30.07^{\mathrm{n}}$ \\
\hline$\%$ change compared to control group & & & -21.62 & -0.11 & -2.65 & $-8 . .21$ & 57.56 \\
\hline$\%$ change compared to diabetic group & & & & & 24.20 & 17.11 & 101.04 \\
\hline Splenocytes number & & $316.85 \pm 20.33$ & $221.33 \pm 43.73^{\mathrm{n}}$ & $316 \pm 27.80^{\mathrm{n}}$ & $216 \pm 12^{\mathrm{n} \#}$ & $302.33 \pm 35.25^{\mathrm{n} \#}$ & $633.3 \pm 57.71^{\mathrm{a}^{*}}$ \\
\hline$\%$ change compared to control group & & & -29.96 & -0.26 & -31.82 & -4.58 & 99.87 \\
\hline$\%$ change compared to diabetic group & & & & & -2.40 & 36.59 & 185.37 \\
\hline IgG level & & $0.334 \pm 0.019$ & $0.562 \pm 0.10^{\mathrm{n}}$ & $0.454 \pm 0.07^{\mathrm{n}}$ & $0.511 \pm 0.04^{\mathrm{n} \#}$ & $0.377 \pm 0.05^{\mathrm{n} \#}$ & $0.422 \pm 0.08^{\mathrm{n}, \#}$ \\
\hline$\%$ change compared to control group & & & 68.26 & 35.92 & 54.54 & 12.12 & 27.27 \\
\hline$\%$ change compared to diabetic group & & & & & -9.07 & -32.91 & -24.91 \\
\hline
\end{tabular}

Data are represented as Mean \pm SE of 8 rats. $P^{a}$ Significant at $P \leq 0.05$ compared to control group. $P^{n}$ Non significant compared to control group. $P^{*}$ Significant at

$P \leq 0.05$ compared to diabetic group. $P^{\sharp}$ Non significant compared to diabetic group.

\section{IgG level}

IgG levels in sera of normal rats supplemented with taurine was non significantly increased $(35.92 \%)$ compared to control group. The pre-and post-treatment with taurine did not significantly reduce the elevation of $\mathrm{IgG}$ level caused by diabetes with a recorded percent changes $(-9.07 \%$ and $-32.91 \%)$. Also amaryl treatments caused a decrease in IgG level reached ($24.91 \%)$.

\section{Histopathological Results \\ Hematoxylin and eosin dye slides}

Histological examination of sections of the control pancreas of rats showed that the pancreatic cells were in normal proportions. The acinar cells, with strong stain, were arranged in lobules with prominent nuclei. The islet cells were embedded in the acinar cells and surrounded by fine capsules (Figure 1A).

In case of pancreas of taurine supplemented rats which were not diabetic the microscopic investigations showed that the structure of both the endocrine pancreas and the exocrine pancreas appeared more or less as the control (Figure 1B).

In sections of pancreas of diabetic non treated rats, vessels and an interlobular haemorrhage was noticed (Figure 1C). In sections of pancreas of diabetic non treated rats, the acinar cells did not look classical. The islets were large and occupied by a uniform eosinophilic material and few atrophic cells. Eosinophilic materials also surrounded the blood vessels and an interlobular haemorrhage was noticed (Figure 1C). In case of diabetic rats treated with amaryl drug, normal section was observed showing the islets of Langerhans surrounded by exocrine part (Figure 1D).

Sections of pancreas of taurine supplemented rats before diabetes induction showed the normal structure of exocrine components. The endocrine components showed hypertrophy or degenerative forms (Figure 1E).

Examination of sections of pancreas of taurine administered rats after diabetes induction showed a normal structure of exocrine and endocrine components. The volume of the islets was smaller than that of the control sections. It seemed to be no inflammatory cell infiltration (Figure 1F).
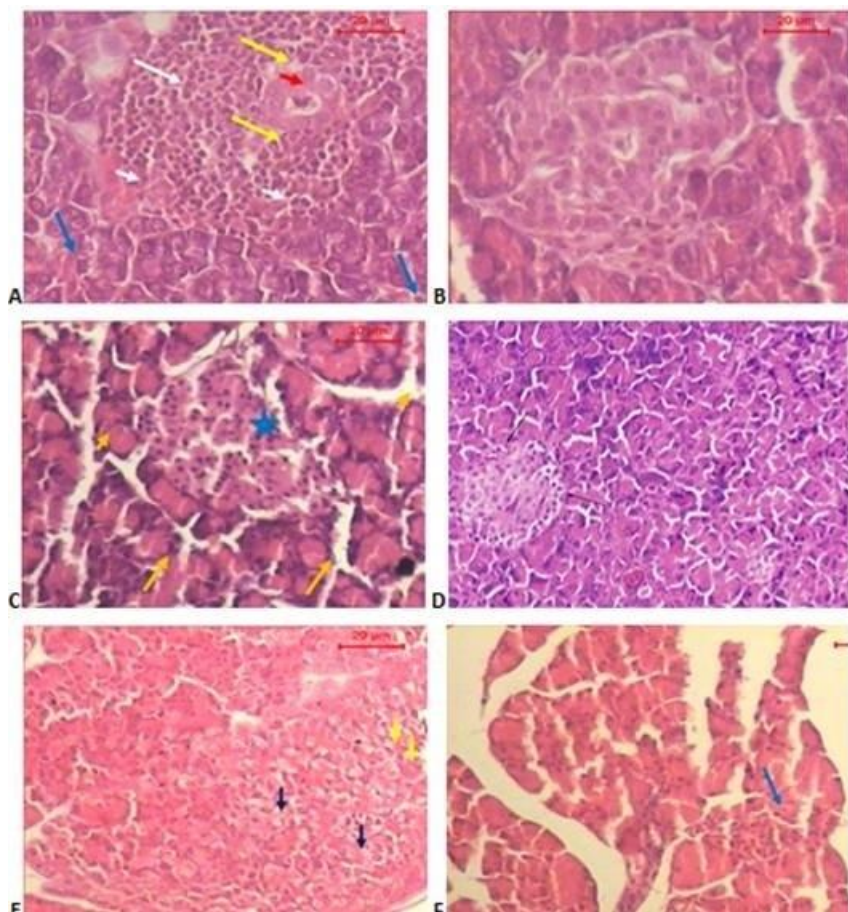

Fig. 1: 1A control ; 1B normal taurine ; 1C diabetic; 1D amaryl; 1E taurine pre-treated; $1 \mathrm{~F}$ taurine post-treated groups. 


\section{Immunohistochemical assay of insulin and glucagon Insulin}

In the control and normal taurine supplemented groups beta cells in the islets of Langerhans appeared normal. Also, the insulin immune-reactivity was shown in a classical pattern in the center of the islets which was stained with deep brown color (Figures 2A and 2B).

Diabetic non treated group showed weak immunereactivity for insulin which reflected the uncompleted destruction of the beta cells secreting insulin while the amaryl treated group showed normal distribution of the immune-reactivity of insulin (Figures 2C and 2D)

For the pre- and post-treated taurine diabetic groups, sections showed a marked reduction in insulin immune-reactivity as compared to the control group (Figures $2 \mathrm{E}$ and $2 \mathrm{~F}$ ).
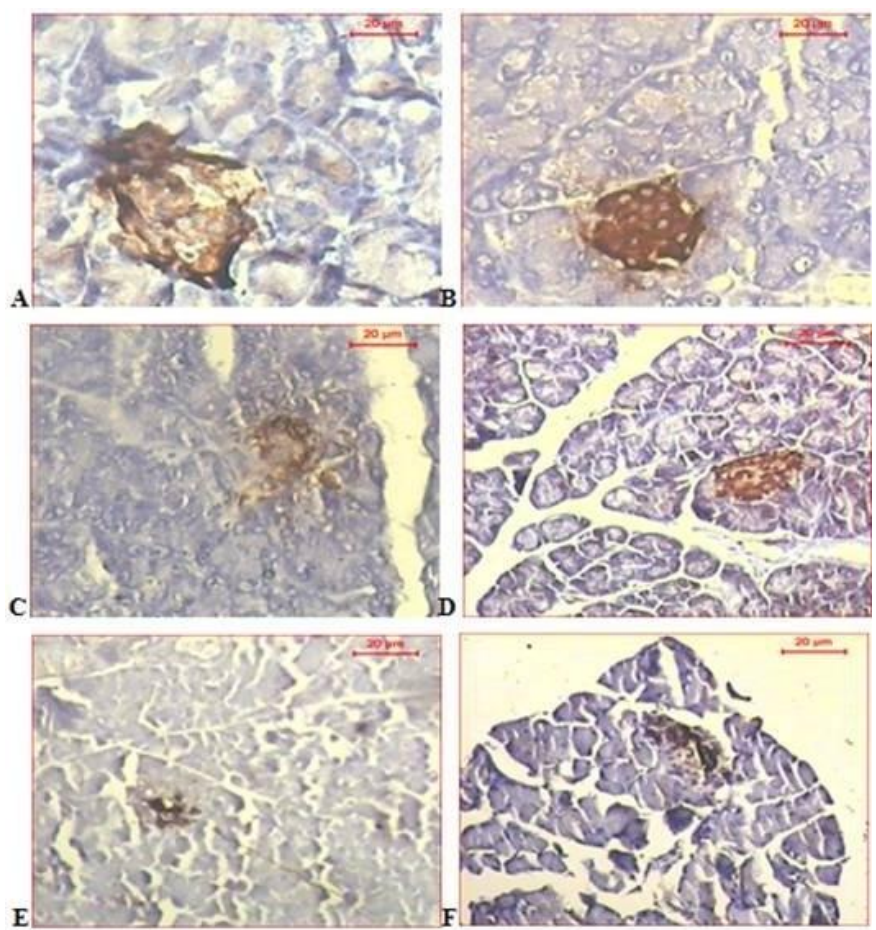

Fig. 2: $2 \mathrm{~A}$ control ; $2 \mathrm{~B}$ normal taurine ; $2 \mathrm{C}$ diabetic; $2 \mathrm{D}$ amaryl; $2 \mathrm{E}$ taurine pre-treated; $2 \mathrm{~F}$ taurine post-treated groups.

\section{Glucagon}

In the control and normal taurine supplemented groups, normal distribution of alpha cells secreating glucagon appeared in the marginal zone of the islets of Langerhans which was stained in brown color (Figures 3A and 3B).

Diabetic non treated group showed much more abundant existence of immune-reactivity for glucagon which revealed absence of the insulin controlling effect on alpha cells due to the destruction of most of the beta cells, on the other hand there was pale immune-reactivity for glucagon in case of amaryl treated group as compared to control group (Figures 3C and 3D).

Normal immune-reactivity for glucagon was observed in the pre-treated taurine diabetic group while there was a reduction in the glucagon immune-reactivity as shown in the therapeutic group compared to normal sections (Figures 3E and 3F, respectively).

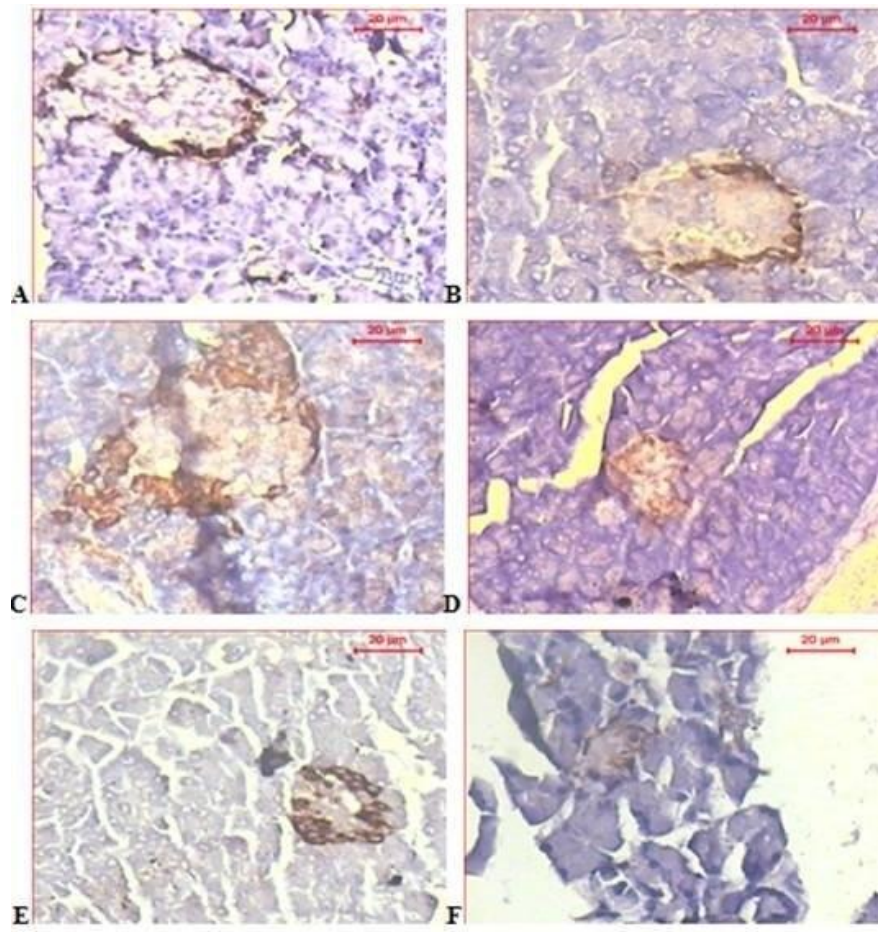

Fig. 3: 3A control ; 3B normal taurine ; 3C diabetic; 3D amaryl; 3E taurine pre-treated; $3 \mathrm{~F}$ taurine post-treated groups

\section{DISCUSSION}

The first goal for controlling diabetes is to reach and maintain the optimum glycated hemoglobin level $\leq 6.5 \%$ (Erejuwa, 2012). Many diabetic patients in whom optimal glycemic goal is achieved, the glycemic control deteriorates even with optimal drug therapy (Cook et al., 2005). The use of medicinal plants and different food supplementations attracted more attention in controlling diabetes in the last decades.

The beneficial effect of taurine in diabetic animals was explained on the fact that taurine shows an antioxidant activity through scavenging of hypochlorite and carbonyl radicals ( Franconi et al., 2004 ; Nonaka et al., 2001). This study aimed to evaluate the impact of taurine on some parameters which are affected by diabetes.

The oxidation of accumulated glucose in diabetes results in the production of hydrogen peroxide and hydroxyl radical (Kajbaf et al., 2007). Accordingly, one of the most important goals to prevent complications of DM is to reduce the production of ROS (Di Naso et al. 2011).

It is shown that post- treatment with taurine to diabetic rats significantly decreased the plasma glucose level similar to the amaryl drug group. Also, significant increase in insulin levels was obtained in both groups. The hypoglycemic impact of taurine could be referred to its anti-oxidant effect. It is supposed that taurine incorporation in mitochondria may affect protein synthesis (Kirino et al., 2004). 
Taurine also has a great effect on the stimulation of insulin secretion either by enhancing the expression of the genes of insulin stimulants, or by inhibiting ATP-sensitive $\mathrm{K}^{+}$channels of $\beta$ cells (Park et al., 2004; Carneiro et al., 2009).

The complications, such as dyslipidaemia, associated with atherosclerosis are common in patients with T2DM. The decrease in insulin activity results in higher intracellular hydrolysis of triglycerides and consequently release in non-esterified fatty acids.

The accumulation of non-esterified fatty acids in the liver, and the relative weak action of insulin are the reasons for a complex alteration in plasma lipids. Even if diabetes is controlled to improve diabetic dyslipidaemia, therapeutic aid is usually required (Krentz, 2003; Samatha et al., 2012).

Improvement in serum total cholesterol and triglycerides levels are observed in our study in both the post-treated taurine group and the amaryl treated group. These improvements may be attributed to the impact of taurine in increasing the uptake of LDL from blood through stimulating its binding with LDL receptor (Stephan et al., 1987; Murakami et al., 2002). The impact of taurine as a hypolipidemic agent may be attributed also to its inhibitory effect of the release of cholesterol from the liver by modulating rate of bile acid conjugation (Nishimura et al., 2009).

Nakaya et al. (2000) showed similar results as ours. They attributed the decrease in cholesterol and triglyceride to taurine treatment.

Murakami et al. (1996) attributed the share of taurine in decreasing the cholesterol level to the activation of cholesterol 7 alpha monooxygenase by taurine, which stimulated bile acid production. Necrotized liver states leads to an increase in liver function enzymes (ALP, AST, ALT, LDH) (Navarro et al., 1993; Ohaeri, 2001). The increase in both transaminases level, AST and ALT in diabetes leads to an increase in serum glucose through converting non carbohydrate sources in the blood to glucose (Ragavan, and krishnakumaris, 2005).

Moreovere, the decrease in insulin and the availability of amino acids in blood lead to increased gluconeogensis and ketogenesis (Ragavan, and krishnakumaris, 2005).

Vozarova et al. (2002) examined the alkaline phosphatase level in normal glucose tolerance individuals and they denoted that there was a relation between the high level of this enzyme and the risk of diabetes. Also Sattar et al. (2004) considered the high level of serum alkaline phosphatase which is easily measured as a prediction for diabetes.

Lactate dehydrogenase, a cytosolic enzyme is involved in biochemical regulation reactions of the body fluids and tissues. It is responsible for the interconversion of lactate to pyruvate. An increase in serum LDH was detected in the diabetic non treated group in the present work. This elevation was in agreement with Mansour et al. (2002) they found an increase in the enzyme in diabetic rats. All these markers showed an improvement in the diabetic rats when supplemented with taurine, where a reduction in their levels is observed. Serum albumin protein is also found to be a parameter affected by diabetes where a decrease in its level is recorded in diabetic non treated rats. This decrease is attributed to the non enzymatic glycation of plasma albumin. Hypoalbuminaemia is considered a marker of malnutrition and the strongest predictor of death in patients with renal failure. Viswanathan et al. (2004) discussed the association of low serum albumin and the fast rate of glomerular filtration in diabetics. Also Mendez et al. (2005) mentioned that the non-enzymatic glycation of albumin was the potential to alter its biological structure and function. Post-treatment of taurine induced a significant elevation in serum albumin compared to diabetic non supplemented animals. These results are an evidence for the anti-diabetic action of taurine.

A significant increase in malonedialdehyde (MDA) was accompanied by a decrease in GR concentration was observed in the diabetic non treated group. These changes are in accordance with Kumawat et al. (2013) who measured similar changes as well as a decrease in glutathione peroxidase (GPx) and glutathione reductase (GR) activities. Anwar and Meki, (2003) attributed the increase in MDA level in liver homogenate due to the oxidative stress in liver cells.

The present results showed an improvement in GR level which is clearly obvious in taurine post-treated group. This improvement was accompanied by a significant decrease in MDA level in liver homogenates. These data assured the antioxidant activity of taurine which in turn reduce the generation of ROS and improve the mitochondrial function through stabilizing the electron transport chain. This assumption was mentioned by Jong et al. (2012) in their studies on the endogenous taurine deficiency in diabetic condition. They reported that the decline in taurine affected the expression of the respiratory chain components required for normal translation of mitochondrial-encoded proteins. From the point of view of immunological role of taurine it was found that taurine regulates the release of pro-inflamatory cytokines in animals and human (Huxtable, 1992).

In another in vitro study it was found that taurine, as a sulfur containing antioxidant, improves the functional capacity of lymphocytes in mice, which in turn enhances the immune response (De la Fuente, 2011). Moreover supplementation of taurine in deficient taurine animals leads to improve depletion of mature and immature B lymphocytes numbers and avoided the decline in $\mathrm{T}$ cells (Grimble, 1996).

The immunomodulatory activity of taurine is through its interaction with hypochlorous compound producing taurine chloramines $(\mathrm{TauCl})$. The immunomodulatory activity of $\mathrm{TauCl}$ is through inhibiting $\mathrm{NO}, \mathrm{PGE}_{2}, \mathrm{TNF} \alpha$ and IL-6 production from stimulated macrophages in culture (Marcinkiewicz et al., 1995).

In the present study, we investigated that taurine was not immunotoxic on thymocytes. No significant change was found in the mean number of thymocytes of non diabetic rat administrated taurine and that of the control group. Our study was in agreement with many authors. Miao et al. (2012) explained that taurine represents a key role in the regulation of the innate immune response and reduce tissue damage induced by bacterial infection by increasing $\mathrm{T}$ regulatory cells. Also Buijs et al. (2013) investigated that taurine may restore the protective 
and immune-enhancing actions and improve clinical outcome in surgical patients. The non significant change in the mean number of neither splenocytes nor IgG levels from rat administrated taurine as compared to normal rats is another evidence for the non immunotoxic effect of taurine. In addition, taurine administration before or after induction of diabetes improved the cellular immune response as compared with cells from amaryl treated rats.

The non immunotoxic effect of taurine on the immune system may be attributed to its anti-inflammatory effect on immune cells. Taurine is found at particularly high concentrations in tissues exposed to elevated levels of oxidants, suggesting its role in the attenuation of oxidative stress.

In the last few decades, taurine attracted the world's attention to its role in the pancreas and $\beta$ cell function.

In a study done by_Bustamante et al. (2001) using the immunolabeled technique on isolated pancreas, they found that taurine was located in the endocrine pancreas in both the nucleus and the cytoplasm. The authors used the goldimmunocytochemical method which confirmed the previous results. They also showed through the gold-immunocytochemical method that $\beta$ cells exhibit in some cases a weak taurine labeling, whereas $\alpha$ - cells were intensely immunostained. The author attributed the lack of taurine in $\beta$-cells to the behavior of taurine as an osmolyte and may diffuse to $\alpha$ cell when the circumstances are changed.

The presence of taurine in the endocrine cells alters islet development (Arany et al., 2004). El Idrissi et al., (2009) also found that taurine supplementation in mice enhances the number and size of pancreatic islets. Santos - Silva et al. (2015) indicated that taurine improves glucose level, through regulating $\beta-, \alpha-$, and $\delta$-cell morphophysiology in obese and diabetic mice, which is an evidence that taurine is one of the therapeutical tool through protecting the pancreatic function in diabetes.

Our histopathological studies showed the moderate effect of taurine as a pre-treatment in defending the pancreas from oxidative stress. At the same time, taurine as a post-treatment successfully normalize the harmful effect of ROS as there was no inflammatory cell infiltration seen and absence of degeneration form. On the other hand, the immunohistochemical studies showed incomplete recovery of both insulin and glucagon in the islets as compared to control. This may suggest that long-term supplementation with taurine is expected to reach curing levels in the endocrine component of pancreas and may reach cure levels of DM.

\section{CONCLUSION}

Taurine as a pre-treatment for STZ induced diabetes showed a mild effect in protecting liver and pancreatic cells against diabetes. The potent effect of taurine in ameliorating diabetic complications is expressed mainly when supplemented as post-treatment for STZ induced diabetes. Surprisingly, taurine therapeutic effect competes with antidiabetic drugs such as amaryl drug which is recommended to T2DM patients. Moreover, its safety besides its numerous advantages makes taurine more preferable than the drug. Accordingly, post-treatment supplementation of taurine is recommended for T2DM.

\section{Abbreviations}

ROS: reactive oxygen species, STZ: streptozotocin, NO: nitric oxide, $\mathrm{PGE}_{2}$ : prostaglandin $\mathrm{E}_{2}, \mathrm{TNF} \alpha$ : tumor necrosis factor alpha, IL-6: interleukin 6.

\section{ACKNOWLEDGMENT}

The authors thank the National Research Center for supporting during the experimental work (The experimental work was ended at 2014).

\section{Financial support and sponsorship: Nil.}

Conflict of Interests: There are no conflicts of interest.

\section{REFERENCES}

Afifi, A. Contrbution to the chemical carcinogensis in Xenopus. Ph. D.Thesis, UCL, Louvain La Neuve, Belgium. 1986; 90- 91.

Alvin, C.P., Kasper. D.L., Brounwal, E., Fauci, A.S. Harrisons principale of internal medicine $16^{\text {th }}$ ed. New York: Mc Graw Hill publishers. 2005; $2152-2172$.

Anwar, M. M. and Meki, A.R. Oxidative stress in streptozotocin-induced diabetic rats effects of garlic oil and melatonin. Comp. Biochem. Physiol., 2003; 135: 539-547.

Arany, E., Strutt, B., Romanus, P., Remacle, C., Reusens, B., Hill, D.J. Taurine supplement in early life altered islet morphology, decreased insulitis and delayed the onset of diabetes in non-obese diabetic mice. Diabetologia. 2004; 47:1831-1837.

Babson, L.A., Greeley, S.J., Coleman, C. Phillips GD, Phenolphthalein monophosphate as a substrate for serum alkaline phosphatase. Clin. Chem. 1966; 12: 482-490.

Buijs, N., Wörner, E.A., Brinkmann, S.J., Luttikhold, J., van der Meij, B.S., Houdijk, A.P., van Leeuwen, P.A. Novel nutritional substrates in surgery. Proc. Nutr. Soc. 2013; 72: 277-287.

Bustamante, J., Lobo, M.V.T., Alonso, F.J., Mukala, N.T.A., Giné, E., Solís, J.M., Tamarit-Rodriguez, J., Martín Del Río, R. An osmotic-sensitive taurine pool is localized in rat pancreatic islet cells containing glucagon and somatostatin. Am. J. Phy. End. Met. 2001; 281.

Carneiro, E.M., Latorraca, M.Q., Araujo, E., Beltra,' M., Oliveras, M.J., Navarro, M., Berna,' G., Bedoya, F.J., Velloso, L.A., Soria, B., Marti'n, F. Taurine supplementation modulates glucose homeostasis and islet function. J. Nutr. Biochem. 2009; 20:503-511.

Cook, M.N., Girman, C.J., Stein, P.P., Alexander, C.M., Holman, R.R. Glycemic control continues to deteriorate after sulfonylureas are added to metformin among patients with type 2 diabetes. Diabetes Care. 2005; 28: 995-1000.

De la Fuente, M., Hernanz, A., Viniegra, S., Miquel, J. Sulfurcontaining antioxidants increase in vitro several functions of lymphocytes from mice. Int. Immunopharmacol. 2011; 11: 661-669.

Di Leo, M.A.S., Santini, S.A., Gentiloni Silveri, N.,Giardina, B., Franconi, F.,Ghirlanda, G. Long-term taurine supplementation reduces mortality rate in streptozotocin-induced diabetic rats. Amino Acids. 2004; 27: $187-191$.

Di Naso, F.C., Simões Dias, A., Porawski, M., Marroni, N.A. Exogenous superoxide dismutase: action on liver oxidative stress in animals with streptozotocin-induced diabetes. Exp Diabetes Res., 2011; 2011: 1-6.

Dumas, B.T. and Biggs, H.G. In standard methods of clinical chemistry, vol 7, Academic press, New York. 1972; 175. 
El Idrissi, A., Boukarrou, L., L'Amoreaux, W. Taurine supplementation and pancreatic remodeling. Adv. Exp. Med. Biol. 2009; 643:353-358.

Erden, M. and Bor, N.M. Changes in reduced glutathione, glutathione reductase and glutathione peroxidase after radiation in guinea pigs. Biochem Med. 1984, 31: 217-227.

Erejuwa, O.O. Mangement of diabetes mellitus: Could simultaneous targeting of hypergycemia and oxidative stress be a better panacea. Int J. Mol. Sci. 2012; 13: 2965-2972.

Finfer, S., Chittock, D.R., Su, S.Y., Blair, D., Foster, D., Dhingra, V., Bellomo, R., Cook, D., Dodek, P., Hendreson, W.R. Intensive versus conventional glucose control in critically ill patients. $\mathrm{N}$. Eng. J. Med. 2009; 360: 1283-1297.

Finlay, J.W.A. and Dillard, R.F. Appropriate calibration curve fitting in ligand binding assays. AAPS Journal. 2007; 9: 260-267.

Franconi, F., Bennardini, F., Mattana, A., Miceli, M., Ciuti, M., Mian, M., Gironi, A., Anichini, R., Seghieri, G. Plasma and platelet taurine are reduced in subjects with insulin-dependent diabetes mellitus: effects of taurine supplementation. Am. J. Clin. Nutr. 1995; 61: 11151119.

Franconi, F., Di Leo, M.A.S., Bennardini, F., Ghirlanda, G. Is taurine beneficial in reducing risk factors for diabetes mellitus? .Neurochem. Res. 2004; 29: 143-150.

Gerstein, HC, Miller, M.E., Byington, R.P., Goff. D.C., Bigger, J.T., Buse, J.B., Cushman, W.C., Genuth, S., Ismail-Beigi, F., Grimm, R.H. Effects of intensive glucose lowering in type 2 diabetes. N. Engl. J. Med. 2008; 358: 2545-2559.

Grimble, R.F. Theory and efficacy of antioxidant therapy. Current Opinion in Critical Care. 1996; 2: 260- 266.

Gornal, A.C., Bardawill, C.J., David, M.M. Determination of serum proteins by means of the biuret reaction. J. Biol. Chem. 1949; 177: 751- 766.

Ha, B.G., Shin, E.J., Park, J., Shon, Y.H. Anti-Diabetic effect of balanced deep-sea water and its mode of action in high-fat diet induced diabetic mice. Mar. Drugs. 2013; 11: 4193-4212.

Herman, W.H., Aubert, R.E., Ali, M.A., Sous, E.A., Badran, A. Diabetes mellitus in Egypt : risk factors, prevalence and future burden. EMH J. 1997; 3: 144 - 148.

Hisalkar, P.J., Patne, A.B., Fawade, M.M. Assessment of plasma antioxidant levels in type 2 diabetes patients. Int. J. Biol. Med. Res. 2012; 3: 1796-1800.

Huxtable, R.J. Physiological action of taurine. Physiol.Rev. 1992; 72:101- 163

Jong, C.J., Azuma, J., Schaffer, S. Mechanism underlying the antioxidant activity of taurine: prevention of mitochondrialoxidant production. Amino Acids. 2012; 42: 2223-2232.

Kachmar, J.F. and Moss, D.W. In fundamentals of clinical chemistry, $2^{\text {nd }}$ ed .NW Tietz, Editor. WB Saunders, Philadelphia. 1976; 652

Kajbaf, F., Mojtahedzadeh, M., Abdollahi, M. Mechanisms underlying stress-induced hyperglycemia in critically ill patients. Therapy. 2007; 4: 97-106.

Kirino, Y., Yasukawa, T., Ohta, S., Akira, S., Ishihara, K., Watanabe K,Suzuki, T. Codon-specific translational defect caused by a wobble modification deficiency in mutant tRNA from a human mitochondrial disease. Proc. Natl. Acad. Sci. 2004; 101:15070-15075.

Krentz, A.J. Lipoprotein abnormalities and their consequences for patients with type 2 diabetes. Diabetes Obes. Metab. 2003; 5: 19-27.

Kumawat, M., Sharma, T.K., Singh, I., Singh, N., Ghalaut, V.S., Vardey, S.K., Shankar, V. Antioxidant Enzymes and Lipid Peroxidation in Type 2 Diabetes Mellitus Patients with and without Nephropathy. N. Am. J. Med. Sci. 2013; 5: 213-219.

Maghraby, A. Effect of bilharcid on the immune system of healthy and Schistosoma mansoni infected mice, Thesis submitted to the Faculty of Science, Cairo University, Egypt. 1989; 43-46.

Maghraby, A.S. and Bahgat, M. Immunostimulatory effect of coumarin derivatives before and after infection of mice with the parasite Schistosoma mansoni. Arzneimittelforschung C. 2004; 54: 445-450.
Mansour, H.A., Newairy, A.A., Yousef, M.I., Sheweita, S.A. Biochemical study on the effect of some Egyptian herbs in alloxan induced diabetic rats. Toxicology 2002; 170: 221-228.

Marcinkiewicz, J., Grabowska, A., Bereta, J., Stelmaszynska, T. Taurine chloramine, a product of activated neutrophils, inhibits in vitro the generation of nitric oxide and other macrophage inflammatory mediators. J. Leukoc. Biol. 1995; 58: 667-674

Mendez, D., Jensen, R., Mcelory, L., Pena, J., Esqurra, R. The effect of non-enzymatic glycation on the unfolding of human serum albumin. Arch. Biochem. Biophys. 2005; 2: 92-99.

Miao, J., Zhang, J., Zheng, L., Yu, X., Zhu, W., Zou, S. Taurine attenuates Streptococcus uberis-induced mastitis in rats by increasing T regulatory cells. Amino Acids. 2012; 42: 2417-2428.

Murakami, S., Yamagishi, I., Asami, Y., Ohta, Y., Toda, Y., Nara, Y., Yamori, Y. Hypolipidemic effect of taurine in stroke-prone spontaneously hypertensive rats. Pharmacology. 1996; 52: 303-13.

Murakami, S., Kondo, Y., Sakurai, T., Kitajima, H., Nagate, T. Taurine suppresses development of atherosclerosis in Watanabe heritable hyperlipidemic (WHHL) rabbits. Atherosclerosis. 2002; 163:79-87.

Nakaya, Y., Minami, A., Harada, N., Sakamoto, S., Niwa, Y., Ohnaka, M. Taurine improves insulin sensitivity in the Otsuka LongEvans Tokushima Fatty rat, a model of spontaneous type 2 diabetes. Am. J. Clin. Nutr. 2000; 71:54-58

Navarro, M.C., Montilla, M.P., Martin, A., Jimenez, J., Utrilla. Free radical scavenger and antihepatotoxic activity of Rosmarinus tomentosus. Planta Med. 1993; 59: 312-314.

Nishimura, N., Yamamoto, T., Ota, T. Taurine feeding inhibits bile acid absorption from the ileum in rats fed a high cholesterol and high fat diet. Adv. Exp. Med. 2009; 643:285-291.

Nonaka, H., Tsujino, T., Watari, Y., Emoto, N., Yokoyama, M. Taurine prevents the decrease in expression and secretion of extracellular superoxide dismutase induced by homocysteine: amelioration of homocysteine-induced endoplasmic reticulum stress by taurine. Circulation. $2001 ; 104: 1165-1170$

Ohaeri, O.C. Effect of garlic oil on the levels of certain enzymes in the serum and tissue of streptozotocin diabetic rats Biosci.Rep. 2001; 21: 19-24.

Park, E.J., Bae, J.H., Kim, S.Y., Lim, J.G., Baek, W.K., Kwon, T.K., Suh, S.I., Park, J.W., Lee, I.K., Ashcroft, F.M., Song, D.K. Inhibition of ATP-sensitive $\mathrm{K}^{+}$channels by taurine through a benzamidobinding site on sulfonylurea receptor 1 . Biochem. Pharmacol. 2004; 67:1089-1096

Patil, S.B., Ghadyale, V.A., Taklikar, S.S., Kulkarni, C.R., Arvindekar, A.U. Insulin secretagogue, alpha-glucosidase and antioxidant activity of of some selected spices in streptozotocin-induced diabetic rats. Plant Foods Human Nutrition. 2011; 66: 85-90.

Pierno, S., De Luca, A., Camerino, C., Huxtable, R.J. Camerino, D.C.Chronic administration of taurine to aged rats improves the electrical and contractile properties of skeletal muscle fibers. J. Pharm. Exp. Therap. 1998; 286:1183-1190.

Ragavan, and krishnakumaris. Effect of Terminalla arjuna stem bark extract on the activities of marker enzymes in alloxan induced diabetic rats. Ancient Science of life, XXV. 2005; 1:8-15.

Ramesh, B. and Pugalendi, K.V. Impact of umbelliferone (7hydroxycourmarin) on hepatic marker enzymes in streptozotocin diabetic rats. Indian J. Pharmacol. 2006; 38: 209-210.

Reitman, S. and Frankel, S. A colorimeteric method for the determination of serum glutamic oxaloacetic, glutamic pyruvic transaminases, A.J. Clinical. Pathol. 1957; 28, 56-63.

Robertson, R.P. Chronic oxidative stress as a central mechanism for glucose toxicity in pancreatic islet beta cells in diabetes. J. Biol. Chem. 2004; 279: 42351-42354.

Ruiz- Larrea, M.B., Leal, A.M., Liza, M., H., Lacort, M., De Groot, H. Antioxidant effects of estradiol and 2- hydroxyestradiol on iron - induced lipid peroxidation of rat liver microsomes. Steroids. 1994; 59: 383- 388.

Samatha, P., Venkateswarlu, M., Siva Parbodh, V. Lipid profile levels in type 2 diabetes mellitus from the tribal population of Adilabad in Andhra Pradesh, India. J. Clin. Diag.Res. 2012; 6: 590 -592. 
Santos-Silva, J.C., Ribeiro, R.A., Vettorazzi, J.F., Irles, E., Rickli, S., Borck, P.C., Porciuncula, P.M., Quesada, I., Nadal, A., Boschero, A.C., Carneiro, E.M. Taurine supplementation ameliorates glucose homeostasis, prevents insulin and glucagon hypersecretion, and controls $\beta, \alpha$, and $\delta$-cell masses in genetic obese mice. Amino Acids. 2015; 47:1533-1548.

Sattar, N., Scherbackova, O., Ford, I., OReilly, D.J., Stanley, A., Forrest, E., Mac Farlane, P.W., Chris, J., Packard, C.J., Cobbe, S.M., Shephers, J. Elevated alanine aminotransferase predicts new - onset type 2 diabetes independently of classical risk factors, metabolic syndrome and $\mathrm{C}$ - reactive protein in the west of Scotland coronary prevention study. Diabetes. 2004; 53: 2855 - 2860.

Shaw, J.E., Sicree, R.A., Zimmet, P.Z. Global estimates of the prevalence of diabetes for 2010 and 2030. Diabetes Res. Clin. Pract. J. 2010; 87: 4 -14.

Stein, E.A. In textbook of clinical chemistry, NW Tietz, ed. WB Saunders, Philadelphia. 1986; 879-886.

Stephan, Z.F., Lindsey, S., Hayes, K.C. Taurine enhances low density lipoprotein binding. Internalization and degradation by cultured Hep G2 cells. J. Biol. Chem. 1987; 262:6069-6073

Viswanathan, V., Snehalatha, C., Kumutha, R., Jayaraman, M., Ramachandran, A. Serum albumin levels in different stages of type 2 diabetic nephropathy patients. Indian J Nephrol. 2004; 14: 89 - 92.

Vozarova, B., Stefan, N., Lindsay, R.S., Saremi, A., Pratley, R.E., Bogardus, C., Tataranni, P.A. High alanine aminotransferase is associated with decreased hepatic insulin sensitivity and predicts the development of type 2 diabetes. Diabetes. 2002; 51:1889-1895.
Wahlefeld, A.W. In methods of enzymatic analysis, $\mathrm{Hu}$ Bergmeyer Ed. Academic Press, New York. 1974; 1831-1835.

Wilson, P.W.F. and Meigs, J.B. Risk of type 2 diabetes mellitus and coronary heart disease: pivotal role for metabolic factors. Eur. Heart J. 2008; 10 supp B: 11-15.

Yamori, Y. Food factors for atherosclerosis prevention: Asian perspective derived from analyses of worldwide dietary biomarkers. Exp. Clin. Cardiol., 2006; 11:94-8.

Yamori, Y., Liu, L., Mori, M. Taurine as the nutritional factor for the longevity of the Japanese revealed by a world-wide epidemiological survey. Adv. Exp. Med. Biol. 2009; 643:13-25.

Yamori, Y., Taguchi, T., Hamada, A., Kunimasa, K., Mori, H., Mori, M. Taurine in health and diseases: consistent evidence from experimental and epidemiological studies. J. Biomed. Sci. 2010; 17.

\section{How to cite this article:}

Foda DS, Farrag EK, Metwally NS, Maghraby AS, Farrag ARH, Rawi SM. Protective and therapeutic impact of taurine on some biochemical, immunological and histological parameters in diabetic rats. J App Pharm Sci, 2016; 6 (10): 045-054. 